\title{
PET for dementia drug test
}

\section{Tokyo}

A Group of seven Japanese companies is expected to launch a government-backed project in April that will use Positron Emission Tomography (PET) of the brain to develop and test new drugs for the treatment of senile dementia. The PET project, which has a particular urgency because of Japan's ageing population, will be supported through the Ministry of Health and Welfare (MHW) as part of a new scheme designed to promote industrial research.

The money for this project comes from a fund originally set aside to provide financial relief to patients who had suffered adverse reactions from drugs. But by 1987 this fund had acquired unused assets of more than $¥ 3,000$ million (more than $\$ 20$ million), and the MHW decided to plough some of the money back into research and development, renaming the organization the Drug Fund for Adverse Reaction Relief and Research Promotion.

Each year two new projects, chosen from applications that must involve two or more companies, are initiated. Last year 13 groups applied, and two of the propoPUBLIC HEALTH

\section{'Wellness Letter' tops subscription stakes}

\section{San Francisco}

THE Wellness Letter, a monthly newsletter of health maintenance published by the School of Public Health of the University of California at Berkeley, has now attracted one million subscribers, making it the most widely circulated newsletter in the United States, the university reported. Founded in 1984 with 28,000 initial subscribers, the $\$ 20$-a-month publication tries to make sense of the sometimes contradictory findings of health researchers on such issues as the effects of caffeine, and recommends ways for people to improve their health.

The eight-page February issue includes articles about decaffeinated coffee, a discussion of the 'empty nest syndrome' suffered by parents who are left alone for the first time in years when their children grow up, and a 'buying guide' section devoted to toothpastes: flossing remains the best tartar-control method, readers are cautioned, despite the claims of some new 'tartar-control' toothpastes.

The newsletter is distributed in Canada, West Germany (as the 'Gesundheit Report'), and Australia as well as the United States. Royalties are being used to sponsor 'Wellness Fellowships' for graduate students, guest speakers and visiting scholars at the School of Public Health.

Robert Buderi sals involved the use of PET scanners. Successful applicants establish a jointventure company and the fund provides up to 70 per cent of required research and development funds (typically $¥ 4,000$ $¥ 5,000$ million ( $\$ 29-\$ 36$ million) over a period of seven years by acquiring stock in the company. After seven years the company can be continued with private funding or dissolved. Intellectual property rights arising out of the research belong to the company.

The successful PET project application comes from a group of four pharmaceutical companies (Takeda Chemical Industries Ltd, Fujisawa Pharmaceutical Co., Yoshitomi Pharmaeutical Industries Ltd and Tanabe Seiyaku Co., Ltd), Wako Pure Chemical Industries, Ltd (a subsidiary of Takeda that deals in diagnostics), Nihon Medifix (a company owned by Hoffmann-La Roche that sells radioisotopes) and Sumitomo Heavy Industries.

Katsura Morita, executive vice-president of Takeda, says that the main purpose of the project will be to discover, appraise and develop new anti-dementia drugs. Senile dementia is a matter of great concern to the Ministry of Health and Welfare because of the rapid ageing of the Japanese society. The group will study the two main types of senile dementia, which are caused by blood vessel obstruction in the brain and by deficiency in neurotransmission. PET will be used to monitor the brain activity under the influence of new drugs.

Takeda has considerable expertise in the development of such drugs and in the rapid synthesis of short-lived radioisotope-labelled materials injected into patients for PET scanning. Sumitomo manufactures mini-cyclotrons that will be used to produce the radioisotopes. One difficulty that the group intends to overcome will be the comparatively poor resolution, about 3-5 $\mathrm{mm}$, of current PET scanners. But Morita is confident that this barrier can be overcome by using suitable image-processing techniques.

Formal announcement of the new project by the ministry is not expected until the end of this month. But the group is already negotiating with a hospital to support the project. It will take about a year to a year and half to put together all the hardware, but Toyokazu Kishi of Takeda says that the group hopes to begin experiments with 'cold' (unlabelled) drugs in April. One of the first drugs the group will look at is Spiperone, a neurotropic and antipsychotic drug marketed by Janssen. Spiperone has a strong affinity to dopamine receptors, making it and its derivatives especially useful for PET brain studies, according to Morita.

David Swinbanks
UK HIGHER EDUCATION Increase or reshuffle? London

THE UK government's plans for public spending for the three years to 1992-93, released last week, contain an increase for higher education of 10 per cent in 1990-91 from 1989-90, with funding remaining at about this level for the following two years. But some of this increase has to be offset against increased costs: the student population is expected to grow by 10 per cent over the same period.

The planning figures reflect the government's desire to move away from meeting university teaching costs through centrally provided grants towards a system of fees. The Universities Funding Council (UFC) and the Polytechnic and Colleges Funding Council (PCFC) are faced with shrinking budgets because, to link teaching provision more closely to student numbers, some UFC and PCFC money is to be transferred to local education authorities (LEAs), whence it will go to education institutions as fees accompanying each LEA-supported student. From next autumn, these fees are to be increased from $£ 607$ per student per year, to $£ 1675$.

The shift in UFC and PCFC money to LEAs is "financially neutral", in terms of overall higher education spending, according to the Department of Education and Science. But there is concern that not enough money from the funding councils' budgets will be left for faculty pay settlements, once funds earmarked for building repairs and restructuring programmes have been removed.

The UFC last week announced a small concession to opponents of its competitive bidding system for student places (see Nature 342, 843; 1989), introduced by the government to accompany the shift towards fees. Universities must state how many students they wish to teach in each subject from 1991-92, and offer a price for teaching costs per student. A list of guide prices, released early in January, was intended to set the maximum teaching costs.

But the UFC has now said that "in exceptional circumstances", it will consider offers above the guide price. It is not yet clear what these circumstances would be, but Sir Peter Swinnerton-Dyer, chief executive of UFC, expects "very few bids above the guide prices to be justifiable".

The government public expenditure plans also include more than $£ 560$ million over three years for the introduction of its controversial student 'top-up loans' scheme. From next autumn, the government intends to freeze the student maintenance grant at its present cash level, providing further finance through loans. The government remains committed to the scheme, despite the major banks' decision, mindful of student custom, not to administer the proposed student loans company.

Peter Aldhous 